\title{
E-Commerce Syariah, a Concept and Implementation in Indonesia
}

\author{
Nugraha Pranadita, Eman Suparman \\ \{nugpra@yahoo.com ${ }^{1}$,eman_professor@yahoo.com ${ }^{2}$ \} \\ Master of Law Studies, Program Post-Graduate School, Islamic University of Nusantara, Bandung, \\ Indonesia $^{1}$, Padjadjaran University, Bandung, Indonesia ${ }^{2}$
}

\begin{abstract}
The largest part of the world community today is Muslim, when Christians and Catholics are separated. Thus Islamic culture should be part of the great flow of world culture. The development of Islam is closely related to the world of commerce. Prophet Muhammad as the prophet of Islam is a merchant. Likewise with the spread of Islam, some of them done through the trade. For a Muslim, trade is not just an economic issue, but a part of worship that must be implemented as Islamic law governs it. De jure is true Indonesia is not an Islamic state, but de fact de pacto most of the people of Indonesia are subject to and implement Islamic law in everyday life. It is only natural that Islamic law also forms part of the trading activities undertaken by Indonesian Muslim societies, including trade through cyberspace known as e-commerce. This research is a normative juridical research applied in the field of technology that is empirical. This allows the results of this study is not just a concept that is normative, but more than that, into something that can be implemented in the daily life of Indonesian society. Finally, the results of this study can prove that Islamic law (sharia) in conventional trade on the boundaries and in certain ways can also be applied in commerce in e-commerce in Indonesia.
\end{abstract}

Keywords: e-commerce, sharia, concept and implementation.

\section{Introduction}

The Pew Research Center on April 2, 2015 published the results of its research entitled The Future of World Religions: Population Growth Projections, 2010-2050 to answer the question of why adherents of Islam in the world develop rapidly, while the number of people who do not affiliate themselves to one religion / trust, the number tends to shrink. The results of his research show that the development of religions in the world is strongly influenced by; (1) birth rate, (2) population in young age, and (3) number of people who change religion. In essence, the results of the study concluded that in 2050:

1. The number of Muslims will be almost the same as the number of Christians.

2. Atheists and those who are not affiliated with any religion will increase in the United States and France, but decrease overall in the world.

3. The number of Buddhists in 2050 will be the same as in 2010, while the number of Hindus and Jews will increase.

4. The population of Muslims in Europe will reach $10 \%$.

5. The majority of Indians are Hindus, but the number of Muslims in India will exceed the number of Muslims in Indonesia. 
6. The number of Christian believers in the United States will decline, the number of Jewish believers is no longer the largest besides Christians, and the number of Muslims will exceed the Jewish faith.

7. Four out of every ten Christians in the world will live in sub-Saharan Africa.

"Islam will be the largest religion in the world in 2075 as babies continue to grow in Muslim families, the study institute of the United States Pew Research Center said" [1]. "The world's population (2013) is 7,021,836,029. Details according to religions are: Islam 22.43\%, Catholic Christian 16.83\%, Protestant Christian 6.08\%, Orthodox 4.03\%, Anglican 1.26\%, Hindu $13.78 \%$, Buddhist $7.13 \%$, Sikh 0.36\%, Jewish 0.21\%, Baha'i 0.11\%, Others $11.17 \%$, Non Religion $9.42 \%$, and Atheists $2.04 \%$ (www.30 days.net)" [2].

The fact shows that currently Muslims are a large part of the world community, thus Islamic culture is one of the main streams of culture in the world. Trust in a religion will in fact affect the pattern of life of the adherents of the religion. In other words, there is a close relationship between religion and the culture of the people who embrace religion. Citing Koentjaraningrat's opinion that culture is; "An idea and a sense, an action and also a work that is a result produced by humans in the life of a community that will later become their own by learning" [3], then community activities in the field of economy or trade can be categorized as part of the culture of that community. The conclusion of this paragraph is; Islamic religion gave birth to Islamic society, Islamic society gave birth to the culture of Islamic society, and the economy (especially trade) in accordance with Islamic sharia is part of the implementation of Islamic culture in everyday people's lives. It is known that there are at least 50 countries in the world where the majority of the population is Muslim (Ilmu Geografi.com). This is certainly a supporting factor for the development of Islamic culture in the trading systems of nations in the world.

It is believed that currently there is no single nation / state that is free from international trade. In general, countries in the world receive foreign exchange from international trade. In addition to international trade, domestic trade in certain parts supports the country's overall economic growth. In practice, international trade and domestic trade other than being carried out conventionally can also be done electronically. In this paper, conventional trade is defined as trading carried out by sellers with direct buyers (meeting directly), while trading electronically occurs when sellers and buyers meet and transact not directly, but by using certain (electronic) media. Electronic commerce is better known as e-commerce, namely "activities related to buying, selling, marketing goods or services using electronic systems such as the internet or computer networks" [4]. Thus e-commerce "is a collection of technologies, applications, and businesses that connect companies or individuals as consumers to conduct electronic transactions, exchange goods, and exchange information through the internet or television, www, or other computer networks".

Based on the description above it can be understood that Islamic culture as part of the main stream of world culture should be properly and appropriately present in the economic field (as part of human culture), especially in terms of trade organized using electronic devices. Thus the identification of the research problem can be formulated as follows:

1. What is the concept of sharia e-commerce in Indonesia?

2. What is the implementation of sharia e-commerce in Indonesia? 


\section{Research Methods}

Because this research is related to the concept of sharia e-commerce and its application in Indonesia, this research is a normative / doctrinal legal research conducted by means of literature study, using secondary data as the primary hukuim material. This research approach is carried out using the existing legislation approach in Indonesia. Thus the truth of this research is pragmatic truth, namely truth that can be justified and that is proven true in general.

\section{Discussion}

One of the ten main trends of the world's extreme future according to James Canton is economic innovation. Economic innovation is formed from ten innovative economic trends that will create prosperity globally, one of the ten economic trends of innovation is innovation breakthroughs through "four means of power", namely; (1) IT and networking, (2) biotechnology, (3) nanotechnology, and (4) neurotechnology. In 2010, information technology pushed two-thirds of increased work productivity. Whereas in 2015 it is estimated that the innovation industry will dominate work productivity throughout the world. In 2010, more than one billion people were connected to the internet, while in 2015 an estimated three billion people will be present online. Maybe at this time James Canton's prediction proved to be incorrect to see the reality around us that the "internet world" has become part of our daily lives. Unwittingly the current pulse needs for some people are no longer tertiary needs, but have become a primary need that must be met every day, just as the need for food sufficiency. In this case the internet speed we get becomes a measure of our daily "nutritional adequacy".

The economy in Indonesia has its regulation in the 1945 Constitution, Article 33 paragraph (4); "The national economy is organized based on economic democracy with the principles of togetherness, efficiency in fairness, sustainability, environmental insight, independence, and by maintaining the balance of progress and national economic unity". To better understand the problem of economic democracy, we can find an explanation in the Decree of the People's Consultative Assembly of the Republic of Indonesia Number XVI / MPR / 1998 concerning Economic Politics in the Context of Economic Democracy, According to Article 3 Tap. The MPR of the Republic of Indonesia stated that: "In the implementation of Economic Democracy, it is not permissible and must be abolished the accumulation of assets and concentration of economic power in a person, group of people or companies that are not in accordance with the principles of justice and equity". Strictly stated that "it is not permissible and must be abolished" the accumulation of assets and concentration of economic power. It can be interpreted that the economic democracy implemented in Indonesia uses a free market mechanism which is a characteristic of the capitalist economic system which is currently the driving force of world trade and globalization in the economic field. The strong process of globalization of the world in various fields has led to a shift in the governance paradigm of rule government to good governance [5]. According to the rule government paradigm; governance, development and public services are based on positive law and are organized by the state. As for the good governance paradigm (the principles of good governance), governance, development and public services are based on positive law, and are held jointly by the government, the business world and the community. In reality the implementation of the paradigm of good governance has the potential to conflict with the 
spirit of economic democracy as referred to in Article 33 paragraph (4) of the 1945 Constitution because it provides opportunities for the private sector (the business world) to carry out "accumulation of assets and concentration of economic forces".

Within certain limits the law is part of society. Homogeneous society is believed to give birth to a homogeneous law as well. While heterogeneous societies will produce heterogeneous (plural) laws as well. A pluralistic Indonesian society can be guaranteed to produce a pluralistic law. Legal pluralism in the positive legal system in Indonesia is a necessity because "constitutional judges and judges are obliged to explore, follow, and understand the legal values and sense of justice that lives in society" [6]. Meanwhile, according to Friedman, "the legal system can be called a plural apable of formal and official laws that differ greatly from living law. This is a universal condition that can be found in national legal systems ". Friedman argues that "legal pluralism means the existence of different legal systems or cultures in a single political community". This is very in accordance with the legal conditions in Indonesia, especially with the still applied colonial law products that are historically, psychologically, and culturally contrary to the socio-cultural conditions of the Indonesian people. The function of the legal system according to Lawrence M. Friedman is; "To distribute and maintain the right allocation of values according to the community". The true values for Muslims are the values that come from the texts (the Qur'an and hadith), thus the function of the legal system is to distribute the values contained in the Qur'an and hadith so that they can be implemented in people's lives (Muslim) everyday.

The nature of legal pluralism is twofold, namely; (1) horizontal legal pluralism, and (2) vertical legal pluralism. Horizontal legal pluralism is composed of similar levels of subsystems. For example Perda (Regional Regulation) about alcohol (liquor); there are regional regulations on alcoholic beverages that are sharia [7], but there are also alcoholic regulations that are non-sharia [8]. In terms of Friedman calls it cultural pluralism [9]. There is also political pluralism like what happens in federalist countries where the law of one state is "equal" to other state laws, Friedman calls it political pluralism. Another horizontal legal pluralism according to Friedman is socioeconomic pluralism. This sociological legal pluralism is defined as legal pluralism that occurs in certain forms of status groups, such as; the law that applies to aristocratic groups is different from the law that applies to ordinary people.

One of the tangible forms of legal pluralism in Indonesia is the recognition of the Islamic banking system and the application of sharia contracts in trade transactions even on a still large scale. Trade transactions in Indonesia are governed by the provisions contained in the Civil Code (KUHPer) and the Commercial Code (KUHD). The authority to settle the dispute is in the hands of the District Court. With the promulgation of the Law of the Republic of Indonesia Number 3 of 2006 concerning Amendments to Law Number 7 of 1989 concerning Religious Courts jo Law of the Republic of Indonesia Number 50 of 2009 concerning the Second Amendment to Law Number 7 of 1989 concerning Religious Courts has given birth a new entity of the economic system in Indonesia, namely the syairah economic system, which in practice is governed by the provisions contained in the Regulation of the Supreme Court of the Republic of Indonesia Number: 02 of 2008 concerning Compilation of Sharia Economic Law. This sharia economic dispute settlement is the authority of the Religious Court to resolve it. So for now, the National Courts and the Religious Courts have the same authority to resolve disputes in the economic field, what distinguishes them is the economic system regime itself. If the conventional (civil) economic regime is used, the settlement of the dispute becomes the authority of the District Court. Whereas if using the Islamic economic huum regime [10], the settlement of the dispute becomes the authority of the Religious Court. 
"The digital revolution has fundamentally changed our concept of space, time and physical objects" [11]. In the marketing mix consisting of 4P (Product, Place, Price, and Promotion) for marketing goods and 6P (Product, Place, Price, Promotion, Power, and Public Relation) for marketing services, known as new marketing channels, namely; "The newest channel for direct marketing is electronics. The internet provides marketers and consumers with far greater opportunities for interaction and individualization" [12]. "Electronic commerce (English: electronic commerce or e-commerce) is the distribution, purchase, sale, marketing of goods and services through electronic systems such as the internet or television, www, or other computer networks. E-commerce can involve electronic fund transfers, electronic data exchanges, automated inventory management systems, and automated data collection systems" [13].

So e-commerce activities related to the existence of the Law of the Republic of Indonesia Number 11 of 2008 concerning Electronic Information and Transactions which was later amended by the Law of the Republic of Indonesia Number 19 of 2016 concerning Amendments to Law Number 11 of 2008 concerning Electronic Information and Transactions . The birth of the law is based on the awareness "that the rapid development and progress of Information Technology has led to changes in the activities of human life in various fields that have directly influenced the birth of new forms of legal action" [14], such as e-commerce transactions.

At present there are at least seven forms of e-commerce business, namely [15]:

1. Business-to-Business (B2B), covering all electronic transactions of goods or services carried out between companies. traditional producers and traders. B2B is done using EDI (Electronic Data Interchange) and e-mail in the process of purchasing goods and or services, information and consulting, or sending and requesting business proposals. EDI is the process of transferring structured data in electronic form using a standard format, which is carried out from one computer system to another computer system.

2. Business-to-Consumer (B2C), trade occurs between companies and end consumers. Usually operated by retailers of traditional retailers. B2C is easier to do and is dynamic.

3. Consumer-to-Consumer (C2C), covering all electronic transactions of goods or services carried out among consumers themselves. In the execution of this transaction is carried out through a third party (service provider) which provides an online platform to carry out the transaction.

4. Consumer-to-Business (C2B), namely; a large group of individuals who sell their services or products to companies seeking these services or products.

5. Business-to-Administration (B2A), namely; all transactions made online between companies and public administration (government), especially related to fiscal services, social security, employment, and others.

6. Consumer-to-Administration (C2A), namely; all electronic transactions carried out by individuals, both as citizens and non-citizens, with public administration (government).

7. Online-to-Offline $(\mathrm{O} 2 \mathrm{O})$. In this case the seller / producer identifies the customers / consumers who normally make purchases / transactions online by using / utilizing email and internet advertising media, then using various methods and approaches to attract the intended customers to leave the online scope and make purchases offline.

Trading transactions both online and offline are basically due to the subject, object and transaction (contract) in question. Trading subjects are people who trade, both on behalf of individuals and on behalf of legal entities. While trading objects are goods and services exchanged by parties in the trade. The transaction (contract) is a certain formality that must be 
carried out by the parties in a trade that allows the trade in question to be carried out properly and legally so that it gets legal protection.

Trading activities are part of general economic activities. Economic activities in accordance with the principles of sharia in Indonesia are carried out as regulated in accordance with the provisions contained in the Compilation of Sharia Economic Law [10]which came into force on September 10, 2008 through the Regulation of the Supreme Court of the Republic of Indonesia Number: 02 of 2008 concerning Compilation of Sharia Economic Law. According to the provisions contained in the KHES, the legal subject is; "Individual, partnership, or business entity that is a legal entity or not a legal entity that has legal ability to support rights and obligations" . Whereas what is meant by people is; "Someone, individual, group of people, or legal entity". The trading objects in the KHES are identified as amwal, namely; "Objects that can be possessed, controlled, cultivated, and transferred, both tangible and intangible objects, both registered and unregistered objects, both movable and immovable objects, and rights that have economic value". Although not clearly stated, objects that can be possessed, controlled, and cultivated according to the text are of course objects that fall into the category of "lawful" law.

Transactions (contracts/akad) in KHES are defined as; "Agreement in an agreement between two or more parties to carry out and or not perform certain legal actions". In the KHES defined 40 types of contracts in the economic field, some of which can be applied in trade.

Table 1. Contracts included in article 20 khes

\begin{tabular}{|c|c|c|}
\hline Num. & Name & Description \\
\hline 1 & Bai' & $\begin{array}{l}\text { 'buying and selling between objects with objects (barter), or } \\
\text { between objects with money }\end{array}$ \\
\hline 2 & Syirkah & $\begin{array}{l}\text { Syirkah collaboration between two or more people in terms of } \\
\text { capital, }\end{array}$ \\
\hline 3 & Mudharabah & $\begin{array}{l}\text { cooperation between the owner of the fund or the investor with } \\
\text { the capital manager to do business with profit sharing based on } \\
\text { the agreed ratio }\end{array}$ \\
\hline 4 & Muzaraah & $\begin{array}{l}\text { collaboration between land owners and land cultivators to utilize } \\
\text { the land }\end{array}$ \\
\hline 5 & Murabahah & $\begin{array}{l}\text { mutual benefit financing carried out by Shahib Al-Mal with } \\
\text { parties in need through a sale and purchase transaction with the } \\
\text { explanation that the price of procurement of goods and selling } \\
\text { prices is of more value which is an advantage for the almal } \\
\text { shahib and the return is made in cash or installments }\end{array}$ \\
\hline 6 & Musaqah & $\begin{array}{l}\text { cooperation between the parties in the maintenance of plants by } \\
\text { sharing the profits between the owner and the keeper of the plant } \\
\text { with a mutually agreed ratio }\end{array}$ \\
\hline 7 & Khiyar & $\begin{array}{l}\text { has the right to vote for sellers and buyers to continue or cancel } \\
\text { the sale and purchase contract }\end{array}$ \\
\hline 8 & Ijarah & rental of goods within a certain period of time with payment \\
\hline 9 & Istisna & $\begin{array}{l}\text { sale and purchase of goods or services in the form of an order } \\
\text { with certain criteria and requirements agreed upon by the parties }\end{array}$ \\
\hline 10 & $\begin{array}{lr}\text { Shunduq } & \text { hifzi } \\
\text { ida'SSafe } & \text { Deposit } \\
\text { Box } & \end{array}$ & $\begin{array}{l}\text { for storing / storing valuables provided by banks with ijarah rent / } \\
\text { ijarah system with risk of compensation }\end{array}$ \\
\hline 11 & Kafalah & $\begin{array}{l}\text { guarantees or guarantees provided by the guarantor to the lender } \\
\text { to fulfill the obligations of the borrower }\end{array}$ \\
\hline 12 & Hawalah & is the transfer of debt from muhil al-ashil to muhal 'alaih \\
\hline 13 & Rahn/gadai & pledge of ownership of the borrower's property by the lender as \\
\hline
\end{tabular}




\begin{tabular}{|c|c|c|}
\hline & & collateral \\
\hline 14 & Ghasb & $\begin{array}{l}\text { takes ownership of others without permission and without } \\
\text { intending to own it }\end{array}$ \\
\hline 15 & Ifsad & damage reduces the quality of the value of an item \\
\hline 16 & Wadi'ah & $\begin{array}{l}\text { is the deposit of funds between the owner of the fund and the } \\
\text { recipient of the deposit }\end{array}$ \\
\hline 17 & Ju'alah & $\begin{array}{l}\text { a certain reward agreement from the first party to the second } \\
\text { party for the implementation of a task performed by a second } \\
\text { party for the first party }\end{array}$ \\
\hline 18 & Wakalah & give power to other parties to do something \\
\hline 19 & $M a b i$ & merchandise that can be exchanged \\
\hline 20 & Saham & $\begin{array}{l}\text { of all things owned by a person / business entity that are put } \\
\text { together into joint property }\end{array}$ \\
\hline 21 & $\begin{array}{l}\text { Syariah } \\
\text { Obligation }\end{array}$ & $\begin{array}{l}\text { bonds issued under the Shari'ah principle as proof of } \\
\text { participation in assets of securities both in rupiah and foreign } \\
\text { currency }\end{array}$ \\
\hline 22 & $\begin{array}{l}\text { Suk maliyah/reksa } \\
\text { dana syariah }\end{array}$ & $\begin{array}{l}\text { Islamic non-bank financial services mutual funds whose } \\
\text { activities are oriented to investment in the portfolio sector / } \\
\text { collective value of securities }\end{array}$ \\
\hline 23 & $\begin{array}{l}\text { Sharia Asset } \\
\text { Backed Securities }\end{array}$ & $\begin{array}{l}\text { Sharia Asset Backed Securities issued by the collective } \\
\text { investment contract of the Sharia Asset Backed Securities whose } \\
\text { portfolio consists of financial assets in the form of bills arising } \\
\text { from commercial securities, bills arising at a later date, buying } \\
\text { and selling ownership of physical assets by financial institutions, } \\
\text { Securities investment nature guaranteed by the government, } \\
\text { means of increasing investment / cash flows and equivalent } \\
\text { financial assets, which are in accordance with Sharia principles. }\end{array}$ \\
\hline 24 & $\begin{array}{l}\text { Sharia } \\
\text { commercial } \\
\text { securities letter of } \\
\text { acknowledgment }\end{array}$ & $\begin{array}{l}\text { Sharia commercial securities letter of acknowledgment of a } \\
\text { financing within a specified period based on sharia principles }\end{array}$ \\
\hline 25 & Ta'min/insurance & $\begin{array}{l}\text { Ta'min / insurance agreement between two or more parties, the } \\
\text { insurer binds itself to the insured by accepting premium fees to } \\
\text { receive compensation to the insured because of loss, damage, or } \\
\text { loss of expected profits, or legal liability to third parties due to } \\
\text { events not sure }\end{array}$ \\
\hline 26 & $\begin{array}{l}\text { Suq } \\
\text { maliyah/capital } \\
\text { market }\end{array}$ & $\begin{array}{l}\text { Suq maliyah / capital market Activities of public offering and } \\
\text { securities trading, public companies that issue securities and } \\
\text { institutions and professions related to securities }\end{array}$ \\
\hline 27 & $\begin{array}{l}\text { Nuqud i'timanil } \\
\text { financing of } \\
\text { provision of funds }\end{array}$ & $\begin{array}{l}\text { Nuqud i'timani / financing of provision of funds based on } \\
\text { mudharabah or musyarakah agreement and or other financing } \\
\text { based on profit sharing principles }\end{array}$ \\
\hline 28 & $\begin{array}{l}\text { Dain/ debt } \\
\text { obligations }\end{array}$ & $\begin{array}{l}\text { debt obligations stated in the amount of money, directly or } \\
\text { contingent }\end{array}$ \\
\hline 29 & Hisab mudayyan & $\begin{array}{l}\text { Reckoning mudayyan / receivable bills arising from buying and } \\
\text { selling transactions and or ijarah based on the murabahah, salam, } \\
\text { istisna, and or ijarah contracts }\end{array}$ \\
\hline 30 & Da'in & lender parties who have receivables due to agreement / by law \\
\hline 31 & Mudayin & Borrowers who have debts due to agreements / by law \\
\hline 32 & Waraqah tijariah & $\begin{array}{l}\text { Waraqah tijariah / Sharia securities investment evidence based on } \\
\text { sharia principles that are commonly traded on markets and or } \\
\text { capital markets }\end{array}$ \\
\hline 33 & Salam & Salam financing services related to buying and selling that \\
\hline
\end{tabular}




\begin{tabular}{|c|c|c|}
\hline & & payment is made in conjunction with ordering goods \\
\hline 34 & Tsaman & aid for merchandise \\
\hline 35 & Qard & $\begin{array}{l}\text { provision of funds between Islamic financial institutions and } \\
\text { borrowers which requires the borrower to make payments in cash } \\
\text { or installments within a specified period }\end{array}$ \\
\hline 36 & Ta'widh & $\begin{array}{l}\text { reimbursement of compensation for real losses paid by the party } \\
\text { that defaults }\end{array}$ \\
\hline 37 & $\begin{array}{l}\text { Corporate Sharia } \\
\text { Financial } \\
\text { Institutions }\end{array}$ & $\begin{array}{l}\text { Corporate Sharia Financial Institutions that collect third party } \\
\text { funds and provide financing to customers }\end{array}$ \\
\hline 38 & $\begin{array}{l}\text { Sunduq mu'asyat } \\
\text { taqa'udi }\end{array}$ & $\begin{array}{l}\text { sharia pension fund business entity that manages and runs } \\
\text { programs that promise pension benefits based on sharia } \\
\text { principles }\end{array}$ \\
\hline 39 & Hisabat jariyat & $\begin{array}{l}\text { Islamic paper accounts finance the funds ijarah can at any time } \\
\text { be withdrawn or deposited by the owner based on sharia } \\
\text { principles }\end{array}$ \\
\hline 40 & Bai' al-wafa' & $\begin{array}{l}\text { buying and selling with the right to repurchase the sale held on } \\
\text { condition that the item sold can be bought back by the seller } \\
\text { based on the agreed time }\end{array}$ \\
\hline
\end{tabular}

\section{Conclusion}

1. The concept of sharia e-commerce in Indonesia is built on the synergy between the KHES, the ITE law and the Religious Courts law as a form of legal pluralism in the Indonesian rule of law.

2. The implementation of sharia e-commerce in Indonesia is by applying sharia principles in the form of contracts as regulated in the KHES into conventional (non-sharia) e-commerce processes.

\section{References}

[1] [2] BBC News Indonesia, "Islam will be the 'biggest religion' in 2075." [Online]. Available: https://www.bbc.com/indonesia/majalah-39510081. [Accessed: 22-Aug-2018].

[2] [16] The Power of 212, "the Number of the World's World's Most Muslim." [Online]. Available: https://thepower212.com/2017/12/18/jilangan-umat-muslim-dunia-terkini/. [Accessed: 22Aug-2018].

[3] [9] Materi IPS.com, "13 Understanding Culture According to Experts." [Online]. Available: https://materiips.com/ cultural understanding. [Accessed: 22-Aug-2018].

[4] [10] Definition of E-Commerce, "Benefits and Benefits of E-Commerce." [Online]. Available: http://dppka.jogjaprov.go.id/upload/files/e-commerce.pdf. [Accessed: 22-Aug-2018].

[5] [15] Sentosa Sembiring, "Investment Law Discussion Equipped with Law Number 25 of 2007 concerning Investment," Nuansa Aulia. 2010.

[6] [17] The Law of the Republic of Indonesia Number 48 of 2009 concerning Judicial Power, "[17] The Law of the Republic of Indonesia Number 48 of 2009 concerning Judicial Power."

[7] [1] BBC Indonesia, "Aceh Passes Islamic Sharia Regional Regulation.” [Online]. Available: http://www.bbc.com/indonesia/berita_indonesia/2014/09/140925_indonesia_qanun_jinayah.

[Accessed: 30-Jul-2018].

[8] [8] Lawrence M. Friedman, Legal System of Social Sciences Perspective. Bandung: Nusamedia, 2013. 
[9] [11] Bandung City Regional Regulation Number, "[11] Bandung City Regional Regulation Number: 11 of 2010 concerning Prohibition, Supervision, and Control of Alcoholic Beverages." .

[10] KHES, "[6] Compilation of Sharia Economic Law."

[11] [12] Philip Kotler, Kotler On Marketing. Tangerang: Karisma Publishing, 2010.

[12] [13] Philip Kotler and Kevin Lane Keller, Marketing Management Edition 12 Volume 2. Jakarta: Index, 2008.

[13] [18] Wikipedia, "Electronic - $\quad$ Trade." [Online]. Available: https://id.wikipedia.org/wiki/Perdag_elektronik. [Accessed: 22-Aug-2018].

[14] [7] Consideration of letter (c), "[7] Consideration of letter (c) of the Republic of Indonesia Law Number 11 of 2008 Challenging Information and Electronic Transactions.".

[15] [14] ProgressTech, "Types of E-Commerce and for example." [Online]. Available: https: //www.progresstech.co.id/blog/jenis-e-commerce/. [Accessed: 22-Aug-2018]. 